\title{
EFFECT OF CHILLING AND ACCUMULATIVE PHOTO-THERMAL UNITS ON FLOWERING OF STRAWBERRY (FRAGARIA $\times$ ANANASSA DUCH.)
}

\author{
Isam A.H. AL-MADHAGI*, Mahassen AL-MUNIBARY, Manssur AL-DOUBIBI \\ Department of Horticulture, Faculty of Agriculture, Sana'a University \\ Sana'a, Yemen
}

Received: November 2017; Accepted: December 2018

\begin{abstract}
The influence of chilling period hours and accumulative photo-thermal unit at different base temperatures, $10,11,13,15$, and $18^{\circ} \mathrm{C}$, on the flowering of strawberry was examined in Sana'a University-Yemen during two seasons: 2006 and 2007. The randomized complete block design (RCBD) field experiment was designed with 5 chilling hours (CHs) periods $\left(0,360,750,1080\right.$, and $1440 \mathrm{CHs}$ under $\left.2 \pm 1^{\circ} \mathrm{C}\right)$, with four replicates each. Accumulative photo-thermal unit (PTU) was calculated for every treatment at different base temperatures for two stages: (i) from planting date to the flower opening (THA) and (ii) from planting date until the end of 2 months (THB). The results revealed that the plants treated with $1080 \mathrm{~h}$ of chilling produced flowers with about $55.12 \%$ and $61.97 \%$ earlier when compared with control (without chilling) in both the seasons, respectively. Stepwise multiple regression analysis showed that both $\mathrm{CHs}$ and the accumulative PTU THA13 (in the first season) and CH plus THA10 (in the second season) have significant effect on days until flower opening, in which the majority effect was related to the chilling period. The effect of chilling period and accumulative PTU at $18^{\circ} \mathrm{C}$ (THB18) had s significant influence $(\mathrm{p}<0.05)$ on the number of early flower per plant, with about $\mathrm{r}^{2}=0.250$ and $\mathrm{r}^{2}=0.536$ in both the seasons, respectively, and $\mathrm{r}^{2}=0.531$ and $\mathrm{r}^{2}=0.740$ for the total effect of both $\mathrm{CH}$ and THB18, respectively. However, the exposure of plants to the long period of chilling (1080 and $1440 \mathrm{~h}$ ) led the plants to produce runners and break up the flowering stage after 9 and 11 weeks in both the seasons, respectively. Meanwhile, plants that received 360-h chilling produced significantly highest $(\mathrm{p}<0.05)$ total number of flowers $(24.83$ per plant), with about $71.2 \%$ higher than that produced by control plants. Moreover, in the second season, plants treated with 750-h chilling produced the significantly higher total number of flowers per plant, with about $50.3 \%$ higher than that of the control. Meanwhile, the 360-h and 750-h chilling periods have similar effect on the number of flowers per plant in the second season. The result showed that the starch level in the crown significantly positively correlated with the days to flower opening $\left(r^{2}=0.415, p=0.05\right)$ and negatively correlated with the number of early flower $\left(\mathrm{r}^{2}=0.587, \mathrm{p}=0.01\right)$. The data from this study might be used for the management of strawberry production.
\end{abstract}

Keywords: strawberry, chilling, photo-thermal unit, flowering

\section{INTRODUCTION}

The cultivated strawberry, Fragaria $\times$ ananassa Duch., is a member of the Rosaceae family. It is cultivated worldwide in about 75 countries covering subtropical, temperate and high-latitude of tropical regions (FAO 2016; Hancock 1999). According to FAO (2016), the world's production of strawberry was increased by $1200.7 \%$ between 1961 and 2016. The estimated total world's production in 2016 was about 9,118,336 tons with planting area of about 401,862 ha. In Yemen, strawberry is widely grown in south and north of the capital city (Sana'a). At the last time, one everbearing cultivar was commercially cultivated in Yemen until 2010. Recently, about four strawberry cultivars have been cultivated in Yemen. 
However, the commercial production of strawberry in Yemen is still significantly smaller, because of the problems such as limited availability of highyielding strawberry cultivars.

One of the most important factors that determined the successful growth and yielding of strawberry is chilling requirement. In the temperate regions, strawberry plants accumulate a sufficient number of chilling hours (CHs) and store carbohydrates in the roots and crowns, whereas shoot remains dormant as a response to the short photoperiods and low temperatures during the autumn and winter (Durner et al. 1984; Maas 1986). On the other hand, chilling requirement is the main point of initiation of strawberry flowers. Sufficient cold conditioning or chilling exposure received by strawberry during the late autumn and winter helps the plants to adapt and grow in the temperate region (Durner et al. 1984; Maas 1986). Meanwhile, inadequate chilling results in low vegetative vigor and reduced vegetative growth, flowering, and fruiting of strawberry (Voth \& Bringhurst 1970; Craig \& Brown 1977; Robert et al. 1997; Bringhurst \& Galletta 1990). Plants with low vegetative vigor flower intensely and produce small fruit (Bringhurst \& Galletta 1990).

Thus, the aim of this study was to determine level of influence of chilling on strawberry flowering associated with the successful production of strawberry fruits under climatic condition in Sana'a. In view of the fact that the cold conditioning or chilling exposure for strawberry grown under the Yemen conditions has not been thoroughly studied, the accumulative photo-thermal units (PTUs) could clarify the effect of chilling. The data from this study might be used for the management of strawberry production under the climatic conditions of Yemen.

\section{MATERIALS AND METHOD}

\section{Plant material and experimental field}

The field experiment was carried out in the Faculty of Agriculture of the Sana'a University in Yemen using local strawberry cultivar. Plants were obtained from lateral crowns on strawberry plantation material obtained from the mother plants, dug from a good farm-growing strawberry at Sanhan District $\left(15^{\circ} 14^{\prime} 55.07^{\prime \prime} \mathrm{N}\right.$ and $44^{\circ} 17^{\prime} 27.60^{\prime \prime} \mathrm{E} ; 14 \mathrm{~km}$ from the capital city, Sana'a) on January $27^{\text {th }}, 2006$ and 2007. High-quality plants were selected (with about $10-\mathrm{mm}$ crown diameter and an average weight of $10 \mathrm{~g}$ ) and divided into 5 groups according to the chilling treatments described in Table 1.

The randomized complete block design (RCBD) field experiment was designed with 5 chilling treatments, which include 4 replicates and 20 plants in every unit experiment (80 per treatment). Plants were treated with a fungicide (Ridomil Gold) after digging. Control plants (0 chilling) were planted in the field immediately after digging. Plants for chilling treatments were separated by 100 pieces into 4 polyethylene plastic bags and exposured to chilling in refrigerator at $2 \pm 1{ }^{\circ} \mathrm{C}$. After exposing to the $\mathrm{CHs}$ described in Table 1, the plants were planted in the experimental field. All plants were equally irrigated and fertilized. Soil characteristics and climatic details are presented in Fig. 1 and Table 2.

Table 1. Description of the experiment

\begin{tabular}{clc}
\hline $\begin{array}{c}\text { Treatment } \\
\text { chilling hour } \pm 2{ }^{\circ} \mathrm{C}\end{array}$ & Treatments & Planting date \\
\hline 0 & Control treatment (without chilling) planting at the plantlets harvesting time & January $27^{\text {th }}$ \\
360 & Storage at $2 \pm 1{ }^{\circ} \mathrm{C}$ for 15 days prior to planting & February $13^{\text {th }}$ \\
750 & Storage at $2 \pm 1^{\circ} \mathrm{C}$ for 30 days prior to planting & March $28^{\text {th }}$ \\
1080 & Storage at $2 \pm 1{ }^{\circ} \mathrm{C}$ for 45 days prior to planting & April $15^{\text {th }}$ \\
1440 & Storage at $2 \pm 1{ }^{\circ} \mathrm{C}$ for 60 days prior to planting & April $30^{\text {th }}$ \\
\hline
\end{tabular}


Table 2. Characteristics of the soil field experiment

\begin{tabular}{lccc}
\hline & First season & Second season & Unit \\
\hline $\mathrm{N}$ & 0.074 & 0.067 & $\%$ \\
$\mathrm{P}$ & 5.74 & 10.73 & $\mathrm{PPM}$ \\
$\mathrm{K}$ & 114.9 & - & $\mathrm{PPM}$ \\
$\mathrm{pH}$ & 8.16 & 8.2 & \\
$\mathrm{EC}$ & - & 0.37 & $\mathrm{~S} \cdot \mathrm{cm}^{-1}$ \\
\hline
\end{tabular}
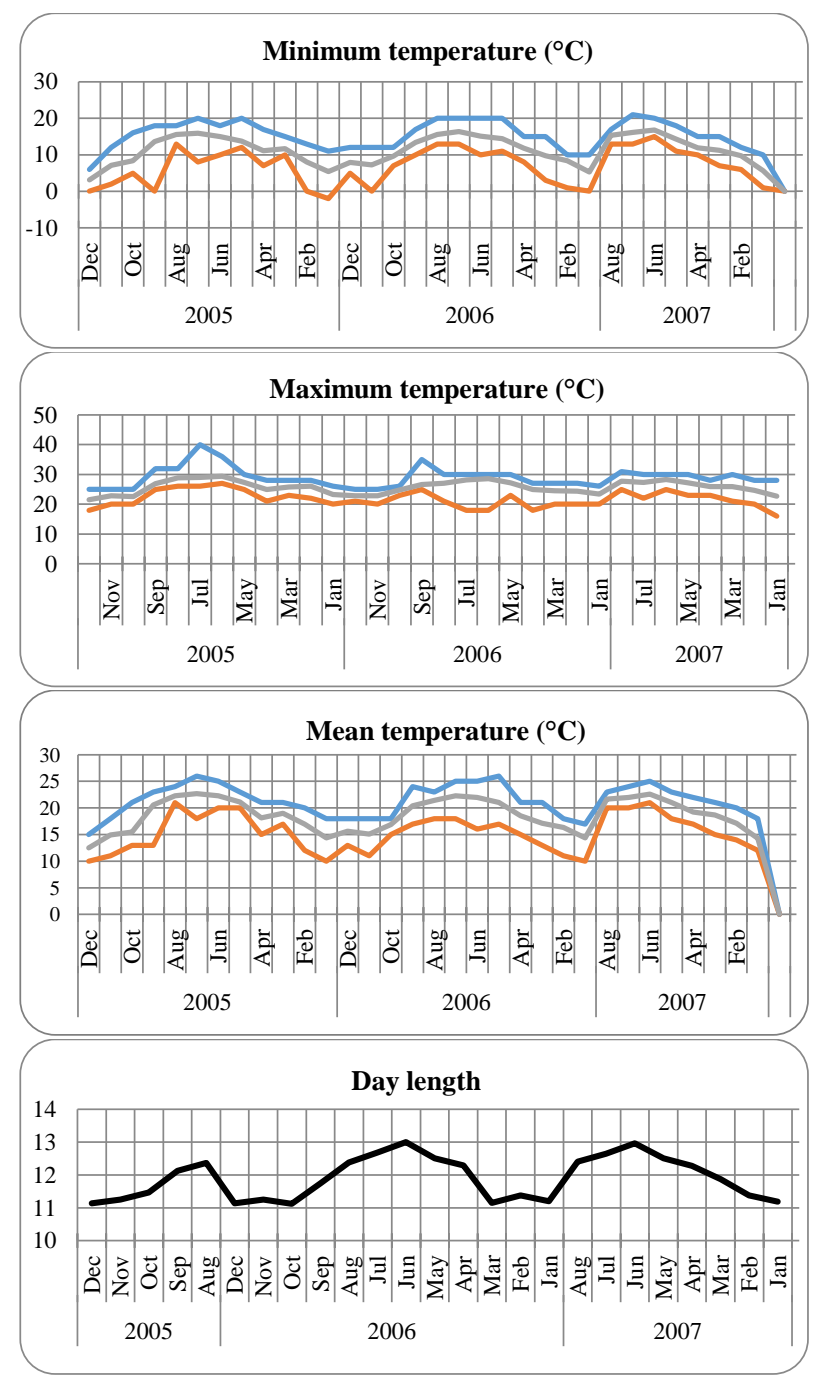

Fig. 1. The highest, lowest, and means of the minimum, maximum, and means of monthly temperature and the average of monthly day length during the field experiment

\section{Flowering characterization}

The following traits were evaluated.

a. Number of days until the flowering of the earliest flowers of all plants was recorded for each experimental unit. b. Early flowers were calculated individually for every plant, and the mean was calculated for each experimental unit (replicates) for the first 2 months from planting date.

c. Total number of flowers was registered weekly for individual plants in each replicate from planting until the end of the experiment (20 weeks from the planting).

\section{Starch analyses}

The fresh and dry weights and the content of the starch in crowns were analyzed at every time of planting, after receiving chilling treatment (Table 1). Ten plants were randomly chosen from the plastic bag after harvest from the chilling. The starch was analyzed from the dried samples. After removing all the soluble materials in the samples, they were subjected to the acidity method using $0.7 \mathrm{~N} \mathrm{HCl}$ to convert starch into soluble sugar. Then the solution was hydrolyzed in a boiling water bath for $2.5 \mathrm{~h}$ and cooled at room temperature, with an equivalent of $0.5 \mathrm{~N} \mathrm{NaOH}$. Then, the samples were diluted, and the soluble sugar was determined calorimetrically using the anthrone reagent method. The absorbance was determined at $630 \mathrm{~nm}$ in a digital UV spectrophotometer (López et al. 2002).

\section{Accumulative photo-thermal units}

Strawberry plants were grown in the field for different number of days after the chilling treatment. It is possible the difference between the treatments related to the temperatures and photoperiod of the time and subsequent of planting. In this case, accumulative PTUs for every treatment were calculated to ensure the effects related to chilling using the following equation: $\mathrm{PTU}=\mathrm{GDD} \times \mathrm{L}$, where $\mathrm{GDD}=$ growing degree day (average of daily temperature base temperature), and $\mathrm{L}=$ daily length hours (measured from the sunrise until sunset).

The accumulative PTUs were calculated for two stages: (i) from the planting date (after chilling treatments) to the first flowers opening stage $(\mathrm{BBCH}$ identification keys of strawberry code $=60$ ) and (ii) from planting date to the end of the 2 months. Although the unit growth (base temperature) was considered as $10,11,13,15$, and $18^{\circ} \mathrm{C}$, the plant accumulates $\mathrm{CHs}$ at a lower temperature of $10{ }^{\circ} \mathrm{C}$ and the optimum temperature for flowering of strawberry plant is $18^{\circ} \mathrm{C}$. 


\begin{tabular}{llc}
\hline & \multicolumn{1}{c}{ BBCH-identification keys of strawberry } & code \\
\hline NEF & Number of early flower per plant & 60 \\
\hline DF & Number of days from planting until flowering & 00 \\
\hline CH & Chilling hour period (treatment) & 60 \\
\hline THA & $\begin{array}{l}\text { Accumulative photo-thermal units from planting date until the beginning of flowering at different } \\
\text { base temperature } 10,11,13,15, \text { and } 18{ }^{\circ} \mathrm{C}\end{array}$ & $\begin{array}{l}\text { Accumulative photo-thermal units from planting date until the end of two months from planting } \\
\text { date at different base temperature }\left(10,11,13,15, \text { and } 18^{\circ} \mathrm{C}\right)\end{array}$ \\
\hline THB
\end{tabular}

\section{Statistical analysis}

The data was statistically analyzed as an RCBD with four replicates using IBM SPSS 21 software. The least significant difference (LSD) was used for the comparison of means amongst the treatments, and the one-way Welch's and Games-Howell tests were used for the comparison of means of runners. Stepwise multiple regression analysis was also used for analyzing the chilling treatment hours and the accumulative PTU. Pearson correlation was used for analyzing the starch level.

\section{RESULT}

Number of days from planting until flowering (DF) The number of days to first flowers open on at least $50 \%$ of plants is given in Fig. 2. Exposure of plants to chilling treatment decreased the period until the flower opening. The chilling for 360, 750, 1080, and $1440 \mathrm{~h}$ reduced the number of days required for flowering by 18, 23, 25 and 21 days, respectively, in the first year and by $11,24,29$, and 24, respectively, in the second year. There were no significant differences in this parameter at $\mathrm{p}<0.05$ amongst chilling for $360,750,1080$, and $1440 \mathrm{~h}$ in the first year and amongst $750,1080 \mathrm{~h}$, and 60 days in the second year.
Moreover, the stepwise multiple regression analysis (Tables $3 \& 4$ ) showed that both $\mathrm{CHs}$ and the accumulative PTUs at $13{ }^{\circ} \mathrm{C}$ from planting date until the first flowers opening have significant effect on the number of days until flowering. In the first season, the influence of both $\mathrm{CH}$ and THA13 from planting date until the flowering elucidated with about $\mathrm{r}^{2}=0.807$ from the total variation effect on the term, where the chilling shown the most influence factor with about $r^{2}=0.497$ of the total compound effects of $\mathrm{CH}$ and THA10. The regression equation used was $\mathrm{DF}=34.34-0.017 \mathrm{CH}+0.005$ HTA13 ( $<$ 0.05). There was no significant effect related to accumulative PTUs at $10,11,15$, and $18{ }^{\circ} \mathrm{C}$ (Table 3).

In the second season, both the variables $(\mathrm{CH}$ and THA10) significantly $(\mathrm{p}<0.05)$ explained about $r^{2}=0.80$ of variation in the number of days from planting until flowering. Meanwhile, the most effected related to the chilling period $(\mathrm{CH})$ with about $r^{2}=0.71$ from the total effect of both variables (CH, THA10). The regression equation used was $\mathrm{DF}=50.851-0.015 \mathrm{CH}+0.003$ THA10. No significant effect was observed on the other accumulative PTU at $11,13,15$, and $18^{\circ} \mathrm{C}$ (Table 4).

Table 3. Stepwise multiple regression analysis on the influence of chilling hour and photo-thermal unit at different base temperatures, $10,11,13,15$, and $18{ }^{\circ} \mathrm{C}$, on the number of days to flowering of strawberry at the first season

\begin{tabular}{|c|c|c|c|c|c|c|c|c|c|}
\hline & Model & $\mathrm{B}$ & $\mathrm{SE} b$ & Beta (B) & $\mathrm{R}$ & $R^{2}$ & $\Delta R^{2}$ & $R^{2}$ Change & F Change \\
\hline \multirow{2}{*}{1} & (Constant) & 47.63 & 2.816 & & \multirow{2}{*}{0.705} & \multirow{2}{*}{0.497} & \multirow{2}{*}{0.469} & \multirow{2}{*}{0.497} & \multirow{2}{*}{17.796} \\
\hline & $\mathrm{Ch}$ & -0.013 & 0.003 & $-0.705 * *$ & & & & & \\
\hline \multirow{3}{*}{2} & (Constant) & 34.34 & 3.110 & & \multirow{3}{*}{0.899} & \multirow{3}{*}{0.807} & \multirow{3}{*}{0.785} & \multirow{3}{*}{0.310} & \multirow{3}{*}{27.375} \\
\hline & $\mathrm{Ch}$ & -0.017 & 0.002 & $-0.869 * * *$ & & & & & \\
\hline & HTA13 & 0.005 & 0.001 & $0.581 * * *$ & & & & & \\
\hline
\end{tabular}

$\Delta R^{2}=$ adjusted $\mathrm{r}^{2}$, HTA13 = accumulative PTU for the first stage (from planting to opening flower) at a base temperature of $13{ }^{\circ} \mathrm{C}$. Other accumulative PTUs at $10,11,15$, and $18^{\circ} \mathrm{C}$ were not significantly influenced and excluded from equation. 
Table 4. Stepwise multiple regression analysis on the influence of chilling hour and photo-thermal unit at different base temperatures, $10,11,13,15$, and $18{ }^{\circ} \mathrm{C}$, on the number of days to flowering of strawberry at the second season

\begin{tabular}{|c|c|c|c|c|c|c|c|c|c|}
\hline & Model & B & SE $b$ & Beta (B) & $\mathrm{R}$ & $R^{2}$ & $\Delta R^{2}$ & $R^{2}$ Change & F Change \\
\hline \multirow{2}{*}{1} & (Constant) & 71.050 & 2.436 & & \multirow{2}{*}{$0.843^{\mathrm{a}}$} & \multirow{2}{*}{0.71} & \multirow{2}{*}{0.69} & \multirow{2}{*}{0.71} & \multirow{2}{*}{44.04} \\
\hline & $\mathrm{Ch}$ & -0.018 & 0.003 & $-0.843 * * *$ & & & & & \\
\hline \multirow{3}{*}{2} & (Constant) & 50.851 & 7.789 & & & & & & \\
\hline & $\mathrm{Ch}$ & -0.015 & 0.003 & $-0.699 * * *$ & $0.893^{b}$ & 0.80 & 0.77 & 0.09 & 7.25 \\
\hline & HTA10 & 0.003 & 0.001 & $0.328 *$ & & & & & \\
\hline
\end{tabular}

$\Delta R^{2}=$ adjusted $\mathrm{r}^{2}$, HTA10 = accumulative PTU for the first stage (from planting to opening flower) at a base temperature of $10^{\circ} \mathrm{C}$. Other accumulative PTUs at $11,13,15$, and $18^{\circ} \mathrm{C}$ were not significantly influenced and excluded from equation.

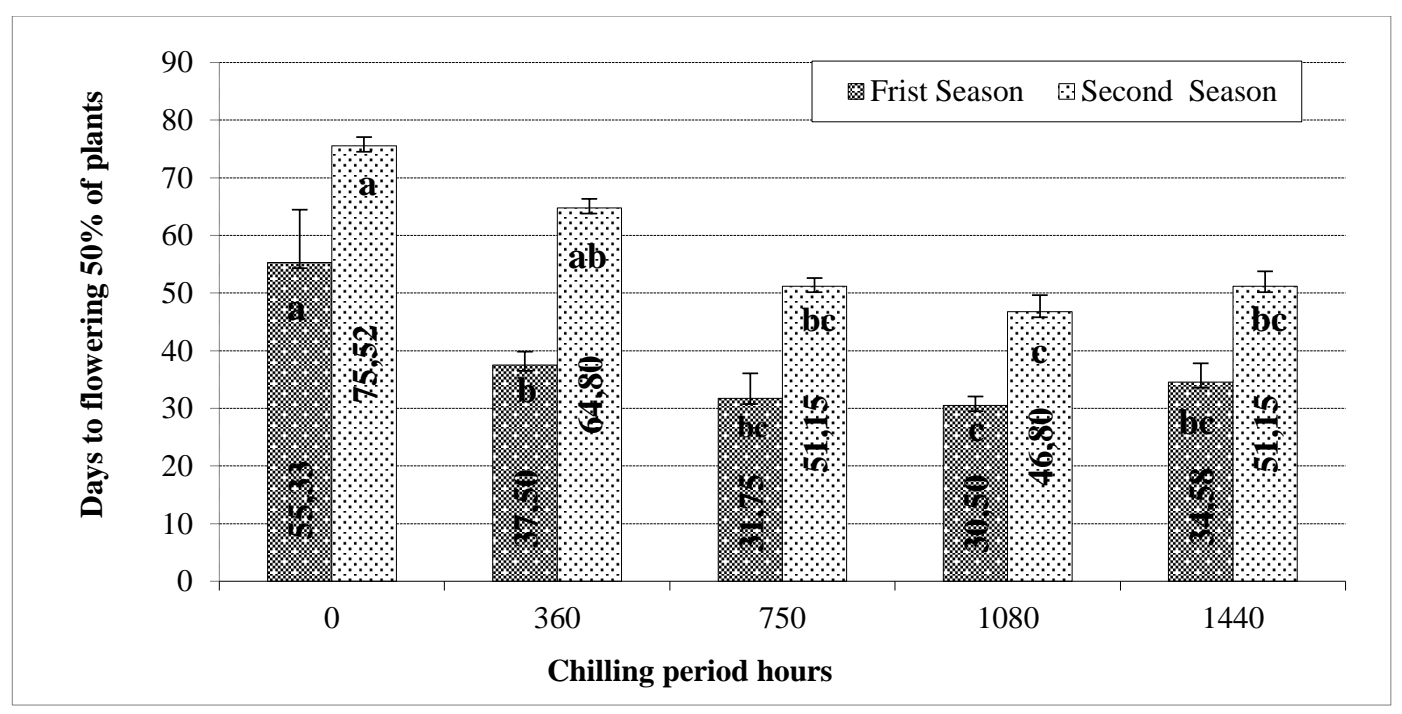

Fig. 2. Effect of chilling hours on the number of days to flower opening of at least $50 \%$ of strawberry plants in both the seasons. Points on bars are means of four replicates are presented. Any two means not followed by the same letter are significantly different $(\mathrm{p}<0.05)$ using the analysis of variance, standard Fisher's protected LSD.

\section{Number of early flower per plant (NEF)}

The results of analysis of variance showed that the plants exposed to $1080 \mathrm{CHs}$ had significantly higher number of early flowers per plant compared with control. Control treatment produced significantly lower number of early flowers in both the seasons (Table 5). Stepwise multiple regression analysis (Table $6 \&$ 7) confirmed that the effect of chilling period (CH) and the accumulative PTUs at $18{ }^{\circ} \mathrm{C}$ (THB18) were the factors, amongst other factors studied $(\mathrm{CH}$ and accumulative PTU from planting date until the end of 2 months at different base temperature 10, 11, 13,15 , and $18^{\circ} \mathrm{C}$ ), that influence the number of early flowers per plant. The effect of chilling period and accumulative PTU at $18{ }^{\circ} \mathrm{C}$ (THB18) had significant influence $(\mathrm{p}<0.05)$ on the number of early flower per plant with about $\mathrm{r}^{2}=0.250$ and $\mathrm{r}^{2}=0.536$, respectively, in both the seasons, with the total effect of both $\mathrm{CH}$ and THB18 as $\mathrm{r}^{2}=0.531$ and $\mathrm{r}^{2}=0.740$, respectively. The effect of chilling period can be calculated using the following equations: $\mathrm{NEF}=0.965+0.009 \mathrm{CH}-$ 0.005 HTB18 (first season) and NEF $=-0.243+$ $0.005 \mathrm{CH}-0.001 \mathrm{HTB} 18$ (second season).

\section{Total number of flowers}

The total number of flowers per plant during the field experiment ( 20 weeks) was significantly influenced by the chilling factor (Figs. $2 \& 3$ ). In the first season, when the plants received 360 -h chilling period, plants produced significantly $(\mathrm{p}<0.05)$ highest number of flowers (24.83 flowers per plant), about $71.2 \%$ higher than that of control plants (Table 5). In the second season, the highest number of flowers was produced when the plants were treated with 750-h chilling period, which was significantly 
higher $(50.3 \%)$ than that of the control. Meanwhile, the effect of 360- and 750-h chilling periods on the number of flowers per plant was at the same level (Table 5).

In contrast, plants treated with 1440 -h chilled period produced the lowest significant number of flowers per plant. It was on a par with those chilled for 1080-h period in both the seasons. The flowering times of plants that received 1440 -h chilling period were discontinued after 9 and 11 weeks from planting in both the seasons, respectively (Fig. 2), whereas those of the plants exposed to 1080-h chilling period were somewhat longer (11 and 13 weeks in the first and second seasons, respectively).

It is worth mentioning that plants that received 1080- or 1440-h chilling period produced runners compared with those treated with other chilling periods (Table 8).

Table 5. Effect of chilling on the number of early flower and total number of flowers per plant in both the seasons

\begin{tabular}{ccccc}
\hline \multirow{2}{*}{ Treatment } & \multicolumn{2}{c}{ Number of early flower } & \multicolumn{2}{c}{ Number of total flower } \\
\cline { 2 - 5 } & first season & second season & first season & second season \\
\hline $0 \mathrm{Ch}$ & $3.04 \pm 0.51 \mathrm{c}$ & $0.3 \pm 0.17 \mathrm{c}$ & $14.5 \pm 1.29 \mathrm{~b}$ & $8.6 \pm 1.61 \mathrm{~b}$ \\
$360 \mathrm{Ch}$ & $6.0 \pm 0.45 \mathrm{ab}$ & $0.58 \pm 0.14 \mathrm{c}$ & $25.2 \pm 4.37 \mathrm{a}$ & $9.7 \pm 2.37 \mathrm{ab}$ \\
$750 \mathrm{Ch}$ & $6.1 \pm 0.43 \mathrm{ab}$ & $2.8 \pm 0.57 \mathrm{~b}$ & $16.0 \pm 2.41 \mathrm{~b}$ & $12.9 \pm 0.85 \mathrm{a}$ \\
$1080 \mathrm{Ch}$ & $7.5 \pm 0.83 \mathrm{a}$ & $4.7 \pm 0.70 \mathrm{a}$ & $10.9 \pm 1.08 \mathrm{bc}$ & $7.2 \pm 0.85 \mathrm{bc}$ \\
$1440 \mathrm{Ch}$ & $5.5 \pm 0.50 \mathrm{~b}$ & $2.9 \pm 0.47 \mathrm{~b}$ & $7.5 \pm 0.86 \mathrm{c}$ & $4.2 \pm 0.98 \mathrm{c}$ \\
\hline LSD $_{0.05}$ & 1.878 & 1.222 & 6.167 & 4.211 \\
\hline
\end{tabular}

Means with SEM (standard error of mean) from four replicates are presented. Number of early flower was calculated as accumulative number of flowers at week 9 , and the total number of flowers per plant was calculated as accumulative number at week 20. Different letters in the same column indicate significant differences ( $\mathrm{p}<0.05$, Fisher's least significant difference test). Different chilling periods used were: 0 or no chilling (control), 360, 750, 1080, and 1440 chilling hours.

Table 6. Stepwise multiple regression analysis on the influence of chilling hour and photo-thermal unit at different base temperatures, $10,11,13,15$, and $18{ }^{\circ} \mathrm{C}$, on the number of early flower per plant at the first season

\begin{tabular}{llcccccccc}
\hline & Model & $\boldsymbol{B}$ & $\mathrm{SE} b$ & Beta (B) & $\mathrm{R}$ & $R^{2}$ & $\Delta R^{2}$ & $R^{2}$ Change & F Change \\
\hline \multirow{2}{*}{1} & (Constant) & 4.378 & 0.619 & & \multirow{2}{*}{0.500} & 0.250 & 0.208 & 0.250 & \multirow{2}{*}{5.994} \\
& CH & 0.002 & 0.001 & $0.500^{*}$ & & & & & \\
\hline \multirow{2}{*}{2} & (Constant) & 0.965 & 1.180 & & & & & & \\
& CH & 0.009 & 0.002 & $2.732^{* *}$ & 0.729 & 0.531 & 0.476 & 0.282 & 10.219 \\
& HTB18 & -0.005 & 0.002 & $-2.294^{* *}$ & & & & & \\
\hline
\end{tabular}

$\Delta R^{2}=$ adjusted $\mathrm{r}^{2}$, HTB18 = accumulative PTU for the second stage (from planting to the end of 2 months) at a base temperature of $18{ }^{\circ} \mathrm{C}$. Other accumulative PTUs at $10,11,13$, and $15^{\circ} \mathrm{C}$ were not significantly influenced and excluded from equation.

Table 7. Stepwise multiple regression analysis on the influence of chilling hour and photo-thermal unit at different base temperatures, $10,11,13,15$, and $18{ }^{\circ} \mathrm{C}$, on the number of early flower per plant at the second season

\begin{tabular}{llcccccccc}
\hline & Model & $\boldsymbol{B}$ & $\mathrm{SE} b$ & Beta (B) & $\mathrm{R}$ & $R^{2}$ & $\Delta R^{2}$ & $R^{2}$ Change & F Change \\
\hline \multirow{2}{*}{1} & (Constant) & 0.380 & 0.503 & & \multirow{2}{*}{$0.732 \mathrm{a}$} & 0.536 & 0.511 & \multirow{2}{*}{0.536} & \multirow{2}{*}{20.821} \\
& Ch & 0.003 & 0.001 & $0.732^{* * *}$ & & & & & \\
\hline \multirow{2}{*}{2} & (Constant) & -0.243 & 0.424 & & & & & & \\
& Ch & 0.005 & 0.001 & $1.387^{* * *}$ & $0.860 \mathrm{~b}$ & 0.740 & 0.709 & 0.203 & 13.270 \\
& HTB18 & -0.001 & 0.000 & $-0.795^{* *}$ & & & & & \\
\hline
\end{tabular}

$\Delta R^{2}=$ adjusted $\mathrm{r}^{2}$, HTB18 = accumulative PTU for the second stage (from planting to the end of 2 months) at a base temperatures $18^{\circ} \mathrm{C}$. Other accumulative PTUs at $10,11,13$, and $15^{\circ} \mathrm{C}$ were not significantly influenced and excluded from equation. 


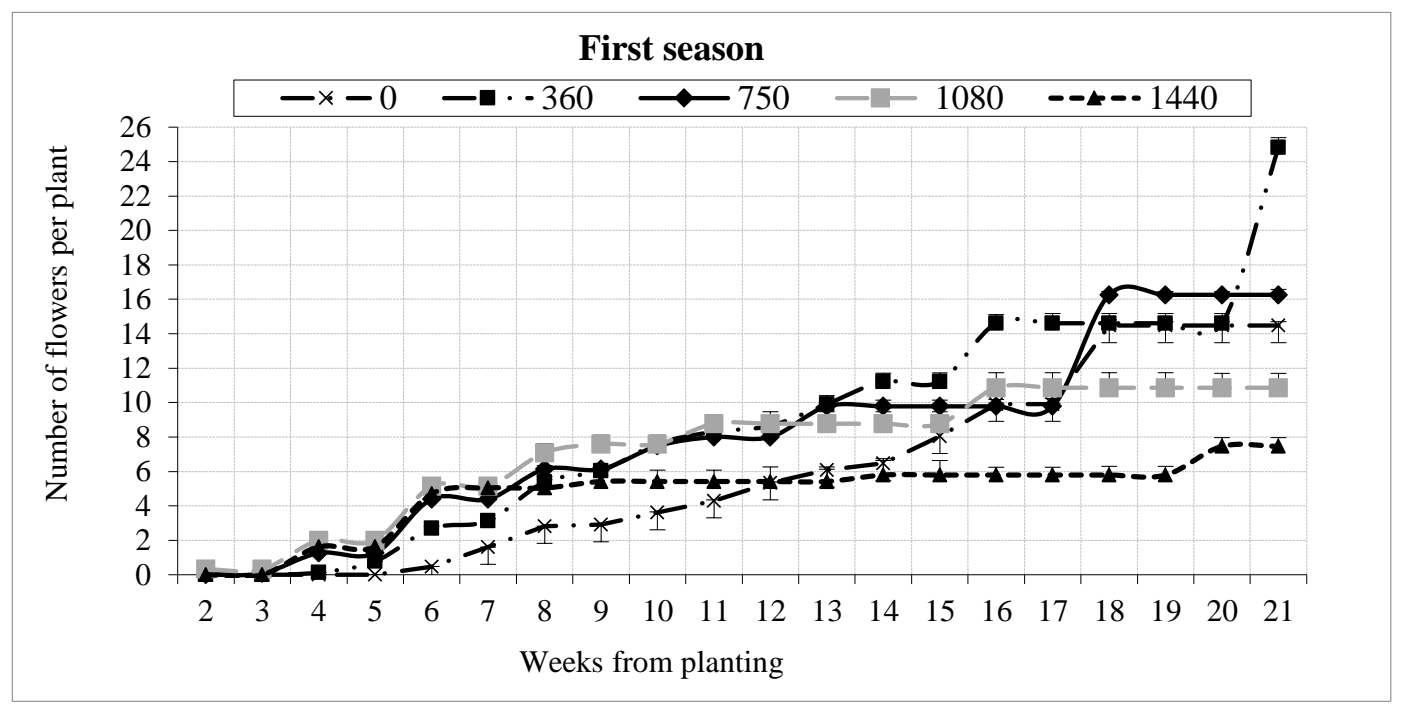

Fig. 3. Effect of chilling treatments on the accumulative number of flowers per plant per weeks during the 20 weeks recorded from the planting of strawberry plant in the first season

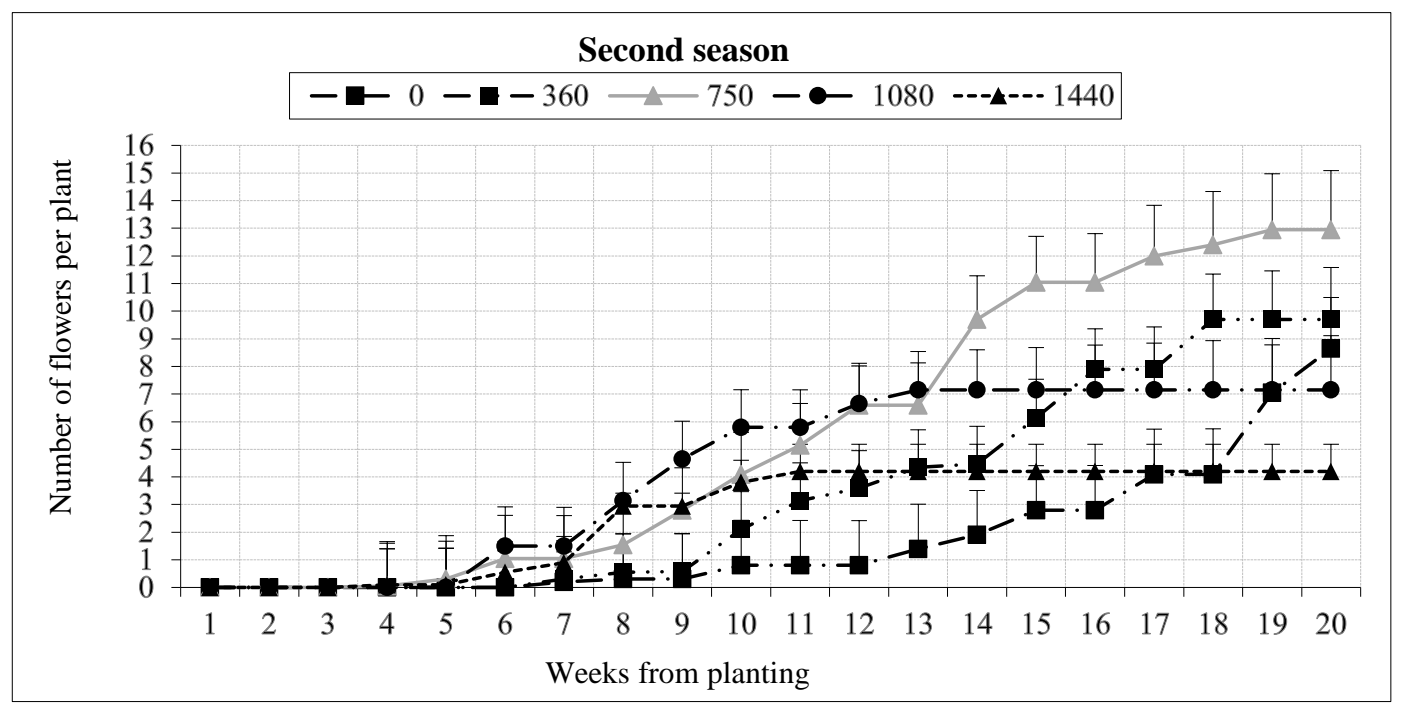

Fig. 4. Effect of chilling treatments on the accumulative number of flowers per plant per weeks during the 20 weeks recorded from the planting of strawberry plant in the second season

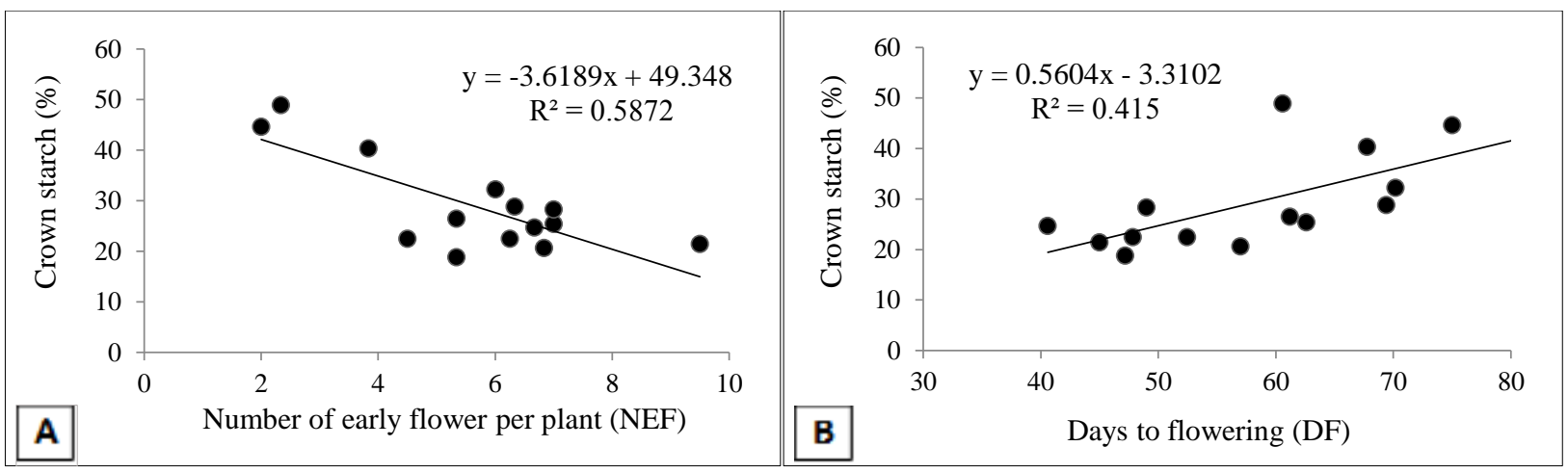

Fig. 5. Correlation (two-tailed) between crown starch and parameters of flowering: A. number of early flower (NEF); B. number of days to flowering (DF). Analysis is based on the means from three replicates of the second season 
Table 8. Means of effect of chilling on the number of runners per plant in both the seasons

\begin{tabular}{lccccc}
\hline \multirow{2}{*}{ Seasons } & \multicolumn{5}{c}{ Treatments } \\
\cline { 2 - 6 } & $0 \mathrm{Ch}$ & $360 \mathrm{Ch}$ & $720 \mathrm{Ch}$ & $1080 \mathrm{Ch}$ & $1440 \mathrm{Ch}$ \\
\hline first & $0.00 \mathrm{c}$ & $0.00 \mathrm{c}$ & $0.00 \mathrm{c}$ & $1.58 \mathrm{~b} \pm 0.31$ & $3.67 \mathrm{a} \pm 0.32$ \\
second & $0.00 \mathrm{c}$ & $0.00 \mathrm{c}$ & $1.0 \mathrm{abc} \pm 0.71$ & $1.72 \mathrm{ab} \pm 0.25$ & $2.37 \mathrm{a} \pm 0.32$ \\
\hline
\end{tabular}

Means with SEM from four replicates are presented. Different letters in the same row indicate significant differences $(\mathrm{p}<0.05)$ using one-way statistics Welch and Games-Howell test. Different chilling periods used were: 0 or no chilling (control), 360, 750, 1080 , and 1440 chilling hours.

\section{DISCUSSION}

Flowering in strawberry plants is related to complex factors, i.e., environmental factors, such as surrounding temperature, introduction of $\mathrm{CH}$ required during fall season and the photoperiods. In addition, it also depends on internal factors such as levels of endogenous hormone and levels of starch and carbohydrate in the roots and the crown (Ito \& Saito 1962; Darrow 1966; Lieten et al. 1995; Lieten 1997; Rohde et al. 2000; Al-Madhagi 2013). As well as it depends on the molecular and genetic basis of winter chill requirement (Atkinson et al. 2013), and the plant age (Verheul et al 2006).

Chilling is need for the initiation of flowers in strawberry (Ito \& Saito 1962; Darrow 1966; Kinet et al. 1993; Lieten 1997). In the current study, the exposure to additional chilling reduced the period to flower initiation (Fig. 1). Starch level on the crown part significantly positive correlated with days to flower opening $\left(\mathrm{r}^{2}=0.41, \mathrm{p}=0.05\right)$, and correlated with number of early flower $\left(r^{2}=0.58, p=0.01\right)$ (Fig. 5). Al-Madhagi (2013) and Al-Madhagi et al. (2014) remarked the decrease in starch level and increase in sucrose levels during the flowering stage. Ito et al. (2002) showed that sucrose metabolism is involved in developing the plant flower bud in Japanese pear.

Accumulative PTU has its effect on the number of days to flower initiation. That explains the role of temperature and photoperiod after chilling exposure. However, subsequent warm temperature to chilling could induce the flower earlier. In addition, temperature and photoperiod have influence on the level of carbohydrates and on the type and level of endogenous hormone (Young 1989; Taiz \& Zeiger 1998; Cutting et al. 1991; Cook \& Bellstedt
2001; Ito et al. 2001; Corbesier et al. 2003; Ahmed \& Ragab 2003; Ulger et al. 2004; Eshghi \& Tafazoli 2007; Al-Madhagi et al. 2012; Al-Madhagi 2013).

Moreover, the growth after exposure to chilling is satisfactorily responsive to the effect of growing degree hours (GDH) (Swartz \& Powell 1981; Lang 1987; Cesaraccio et al. 2004, 2006; Atkinson et al. 2013). Forcing Fragaria after a short period of dormancy influences not only the vegetative growth but also the floral capacity (Piringer \& Scott 1964; Kronenberg \& Wassenaar 1972). This could probably explain the reason for the earlier initiation of flowering in plants that received more chilling than those with no chilling.

Long chilling period (1080 and 1440 hours) reduced the length of flowering period. But all plants that received chilling for 1080 and 1440 hours produced the runners. Even though the experimental strawberry cultivar is everbearing, none produced runners under Sana'a climate conditions. However, the exposure to chilling for 1080 or 1440 hours changed the behavior of this cultivar to grow like Junebearing by producing runners (Table 8 ). Strawberry plants exposed to plenty of chilling produced many runners (Guttridge 1969; Bringhurst et al. 1960; Porlingis \& Boynton 1961; Bailey \& Rossi 1965; Piringer \& Scott 1964; Braun \& Kender 1985; Kahangi et al. 1992; Risser \& Robert 1993; Lieten 1997; Tehranifar et al. 1998; Bigey 2002; Hokanson et al. 2004; Taghavi \& Aghajani 2017). Longer durations of chilling lead to the shorter flower differentiation (Lieten 2006). This result takes the same direction with Avigdori-Avidov et al. (1977), who found that the increase in runner production of 'Tioga' and 'Fresno' and the decline in inflorescence formation came into full expression with longer periods of chilling. 
Meanwhile, if the strawberry plant did not receive the satisfactory amount of chilling, the growth will be sluggish and would not form high fruits (Smeets 1982; Yangagi \& Oda 1992). Tehranifar et al. (1998) found the field chilling was more effective than that carried out using cold storage in the dark. Meanwhile, $F$. $\times$ ananassa does not true dormancy as observed with most members of the Rosaceae, where the short-day cultivars adapted to cool winters will grow in the tropical regions, and the full production will be achieved by required chilling (Arney 1956). The growth and development of strawberry after chilling is responsive to the endogenous hormone. For example, Waithaka et al. (1980) suggested that in vitro, the axillary buds of strawberry released from dormancy were responsive to a CK : GA ratio.

Kirschbaum (1998) found that exposing strawberry plant to more chilling reduced the flower initiation. Okasha and Ragab (1993) found a negative correlation between the period of artificial chilling and flowering of 'Pajaro' and 'Selva' strawberries. A similar result was also obtained by Kinet et al. (1993) in 'Elsanta' with chilling 50-300 CHs. Meanwhile, Lieten et al. (1995) explained that the number of strawberry flowers was lessened by longer cold storage. The current study found that the number of the flower was increased by adding more chilling (360 or 750 hours of chilling) above the natural $\mathrm{CH}$ (above the control). It could be explained that the natural $\mathrm{CH}$ during the winter (about $139 \mathrm{CH}$, calculated as degree < 7.2) was less satisfactory to flowering. In general, the effect of cold storage or artificial chilling was linked to the cultivars (Iyer 1975).

Furthermore, large variation in chilling requirement exists for $F$. $\times$ ananassa adapted to different climatic regions (Darrow 1955; Kronenberg $\&$ Wassenaar 1972). That may explain the reason for the flowering stage after 9 and 11 weeks from plants that received 1080- and 1440-h chilling treatments. The difference in the results between the years may be related to the climate under which the plants grown before chilling accrued and during the growth and development of the plant after chilling treatment. The natural $\mathrm{CHs}$ were higher in the first season than the second season.

\section{CONCLUSION}

It could be concluded that exposure of strawberry to chilling under climate conditions in Sana'a might be able to substitute the natural chilling. Chilling for $360 \mathrm{~h}$ increased the total number of flowers. Chilling for 1080 or $1440 \mathrm{~h}$ increased the production of runners. It is suggested that entering and study new cultivars in term of chilling, and breeding between the local and the other cultivars.

\section{REFERENCES}

Ahmed H.F.S., Ragab M.I. 2003. Hormone levels and protein patterns in dormant and non-dormant buds of strawberry, and induction of bud break by gibberellic acid. Egyptian Journal of Biology 5: 35-42.

Al-Madhagi I. 2013. Influence of photoperiod and exogenous hormone on growth and development of strawberry (Fragaria $\times$ ananassa Duch.). Ph.D., Faculty of Agrotechnology and Food Science, University Malaysia Terengganu.

Al-Madhagi I.A.H., Hasan S.M.Z., Ahmad A., Yusoff W.A. 2012. Changing of the cytokinin (CK) content during the growth and development of strawberry (Fragaria $\times$ ananassa Duch). Conference: UMTAS 2012. Malaysia

Al-Madhagi I.A.H., Hasan S.M.Z., Ahmad A., Yusoff W.A. 2014. The starch status during growth and development of strawberry plant under tropical climatic condition. Acta Horticulturae 1024: 115120. DOI: 10.17660/actahortic.2014.1024.11.

Arney S.E. 1956. Studies of growth and development in the genus Fragaria. IX. Aninvestigation of floral initiation under natural conditions. Phyton 7: 89-102.

Atkinson C.J., Brennan R.M., Jones H.G. 2013. Declining chilling and its impact on temperate perennial crops. Environmental and Experimental Botany 91: 48-62. DOI: 10.1016/j.envexpbot.2013.02.004.

Avigdori-Avidov H., Goldschmidt E.E., Kedar N. 1977. Involvement of endogenous gibberellins in the chilling requirements of strawberry (Fragaria $\times$ ananassa Duch.). Annals of Botany 41: 927-936. DOI: 10.1093/oxfordjournals.aob.a085389.

Bailey J.S., Rossi A.W. 1965. Effect of fall chilling, forcing temperature, and day length on the growth and flowering of Catskill strawberry plants. Proceedings of the American Society for Horticultural Science 87: 245-252. 
Bigey J. 2002. Chilling requirements and compensation for the lack of chilling in strawberry. Acta Horticulturae 567: 269-272.

Braun J.W., Kender W.J. 1985. Correlative bud inhibition and growth habit of the strawberry as influenced by application of gibberellic acid, cytokinin and chilling during short day length. Journal of the American Society for Horticultural Science 110: 28-34.

Bringhurst R.S., Galleta G.J. 1990. Strawberry management. In: Galleta G.J., Himmilrick D.G. (Eds.), Small Fruit Crop Management. Prentice-Hall, USA.

Bringhurst R.S., Voth V., van Hook D. 1960. Relationship of root starch content and chilling history to performance of California strawberries. Proceedings of the American Society for Horticultural Science 75: 373-381.

Cesaraccio C., Spano D., Snyder R., Duce P. 2004. Chilling and forcing model to predict bud-burst of crop and forest species. Agricultural and Forest Meteorology 126: 1-13.

Cesaraccio C., Spano D., Snyder R.L., Duce P., Jones H.G. 2006. Improvement of chilling and forcing model to predict bud-burst. In: Paper Presented at the 17th Conference on Biometeorology and Aerobiology, San Diego.

Cook N.C., Bellstedt D.U. 2001. Chilling response of 'Granny Smith' apple lateral buds inhibited by distal shoot tissues. Scientia Horticulturae 89: 299-308.

Corbesier L., Prinsen E., Jacqmard A., Lejeune P., Onckelen H.V., Perilleux C., Bernier G. 2003. Cytokinin levels in leaves, leaf exudates and shoot apical meristem of Arabidopsis thaliana during floral transition. Journal of Experimental Botany 54: 2511-2517.

Craig D.L., Brown G.L. 1977. Influence of digging date, chilling, cultivars and culture on glasshouse strawberry production in Nova Scotia. Canadian Journal Plant Science 57: 571-576.

Cutting J.G.M., Strydom D.K., Jacobs G., Bellstedt D.U., Van der Merwe K.J., Weiler E.W. 1991. Changes in xylem constituents in response to rest-breaking agents applied to apple before bud break. Journal of the American Society of Horticultural Science 116: 680-683.

Darrow G.M. 1955. Effects of temperature and day length on the varietal adaptation of strawberry. Fruit Varieties and Horticultural Digest 10: 37-54.

Darrow G.M. 1966. The strawberry: history, breeding and physiology. Holt, Rinehart and Winston, 447 p.
Durner E.F., Barden J.A., Himelrick D.G., Poling E.B. 1984. Photoperiod and temperature effects on flower and runner development in day-neutral, June bearing, and everbearing strawberries. Journal of the American Society for Horticultural Science 109(3): 396-400.

Eshghi S., Tafazoli E. 2007. Possible role of cytokinins in flower induction in strawberry. American Journal of Plant Physiology 2(2): 167-174.

FAO 2016. FAOSTAT Agricultural Statistics Database. http://www.fao.org. (Accessed 10 March 2018).

Guttridge C.G. 1969. Fragaria. In: Evans L.T. (Ed.), The induction of flowering. Cornell Univ. Press, Ithaca, pp. 247-267.

Hancock J.F. 1999. Strawberries. CAB International Publishing, USA.

Hokanson S.C., Takeda F., Enns J.M., Black B.L. 2004. Influence of plant storage duration on strawberry runner tip viability and field performance. HortScience 39(7): 1596-1600.

Ito A., Hayama H., Kashimura Y., Yoshioka H. 2001. Effect of maleic hydrazide on endogenous cytokinin contents in lateral buds and its possible role in flower bud formation on the Japanese pear shoot. Scientia Horticulturae 87: 199-205.

Ito A., Hayama H., Kashimura Y. 2002. Sugar metabolism in buds during flower bud formation: a comparison of two Japanese pear (Pyrus pyrifolia (Burm.) Nak.) cultivars possessing different flowering habits. Scientia Horticulturae 96(1): 163175. DOI: 10.1016/S0304-4238(02)00122-X.

Ito H., Saito T. 1962. Studies on the flower formation in the strawberry plants. I. Effects of temperature and photoperiod on the flower formation. Tohoku Journal of Agricultural Research 13: 191-203.

Iyer C.P.A. 1975. Effect of short duration chilling on the performance of strawberry. Indian Journal of Horticulture 32(1-2): 31-34.

Kahangi E.M., Fujime Y., Nakamura E. 1992. Effects of chilling and growth regulators on runner production of three strawberry cultivars under tropical conditions. Journal of Horticultural Science 67: 381-384. DOI: $10.1080 / 00221589.1992 .11516262$.

Kinet J.M., Parmentier A., Lieten F. 1993. Changes in quality of cold-stored strawberry plants (cv. Elsanta) as a function of storage duration: The flowering response in controlled environments. Acta Horticulturae 348: 287-293.

Kirschbaum D.S. 1998. Temperature and growth regulator effects on growth and development of strawberry 
(Fragaria $\times$ ananassa Duch.). Master of Science, vol. 144. University of Florida, USA.

Kronenberg H.G., Wassenaar L.M. 1972. Dormancy and chilling requirements of strawberry varieties for early forcing. Euphytica 21: 454-459.

Lang G.A. 1987. Dormancy: a new universal terminology. HortScience 22: 817-820.

Lieten F. 1997. Effects of chilling and night-break treatment on greenhouse production of 'Elsanta'. Acta Horticulturae 439: 633-640.

Lieten F., Kinet J., Bernier G. 1995. Effect of prolonged cold storage on the production capacity of strawberry plants. Scientia Horticulturae 60: 213-219.

Lieten P. 2006. Chilling unit model for greenhouse production of strawberry cv. 'Elsanta'. Acta Horticulturae 708: 381-388.

López S., Maroto J.V., San Bautista A., Pascual B., Alagarda J. 2002. Differences in carbohydrate content of waiting-bed strawberry plants during development in the nursery. Scientia Horticulturae 94(1/2): 53-62.

Maas J.L. 1986. Photoperiod and temperature effects on starch accumulation in strawberry roots. Advances in Strawberry Production 5: 22-24.

Okasha K., Ragab M.I. 1993. Cold storage effects on performance and yield of strawberry plants. Acta Horticulturae 348: 277.

Piringer A.A., Scott D.H. 1964. Interrelation of photoperiod, chilling, and flower cluster and runner production by strawberries. Proceedings of the American Society for Horticultural Science 84: 295-301.

Porlingis I., Boynton D. 1961. Growth responses of the strawberry plant Fragaria chiloensis var. ananassa, to gibberellic acid and to environmental conditions. Proceedings of the American Society for Horticultural Science 78: 261-269.

Risser G., Robert F. 1993. What cold treatments promote growth in strawberry? Acta Horticulturae 348: 381-383.

Robert F., Petel G., Risser G., Gendraud M. 1997. Determination of the growth potential of strawberry plants (Fragaria $\times$ ananassa Duch.) by morphological and nucleotide measurements, in relation to chilling. Canadian Journal of Plant Science 77: 127-132.

Rohde A., Howe G.T., Olsen J.E., Moritz T., Van Montagu M., Juntilla O., Boerjan W. 2000. Molecular aspects of bud dormancy in trees. In: Jain S.M., Minocha S.C. (Eds.), Molecular Biology of Woody Plants, vol. 1. Kluwer, Dordrecht, pp. 89-134.
Smeets L. 1982. Effect of chilling on runner formation and flower initiation in the everbearing strawberry. Scientia Horticulturae 17: 43-48.

Swartz H.J., Powell L.E., 1981. The effects of long chilling requirements on time of bud break in apple. Acta Horticulturae 120: 173-178.

Taghavi T., Aghajani M. 2017. Effect of chilling duration on runner production and vegetative growth of ' $\mathrm{Pa}$ jaro' strawberry. Acta Horticulturae 1156: 505508. DOI: 10.17660/ActaHortic.2017.1156.75

Taiz L., Zeiger E. 1998. Plant physiology, $2^{\text {nd }}$ ed. Sinauer Associates, Massachusetts, USA.

Tehranifar A., Le Miere P., Battey N.H. 1998. The effects of lifting date, chilling duration and forcing temperature on vegetative growth and fruit production in the June bearing strawberry cultivar Elsanta. Journal of Horticultural Science and Biotechnology 73: 453460. DOI: 10.1080/14620316.1998.11510998.

Ulger S., Sonmez S., Karkacier M., Ertoy N., Akdesir O., Aksu M. 2004. Determination of endogenous hormones, sugars and mineral nutrition levels during the induction, initiation and differentiation stage and their effects on flower formation in olive. Plant Growth Regulation 42: 89-95.

Verheul M.J., Sonsteby A., Grimstad S.O. 2006. Interactions of photoperiod, temperature, duration of short-day treatment and plant age on flowering of Fragaria $\times$ ananassa Duch. cv. Korona. Scientia Horticulturae 107: 164-170. DOI: 10.1016/j.scienta.2005.07.004.

Voth V., Bringhurst R.S. 1970. Influence of nursery harvest date, cold storage, and planting date on performance of winter planted California strawberries. Journal of the American Society of Horticultural Science 95: 496-500.

Waithaka K., Hildebrandt A.C., Dana M.N. 1980. Hormonal control of strawberry axillary bud development in vitro. Journal of the American Society of Horticultural Science 105: 428-430.

Yangagi T., Oda T. 1992. Effects of winter chilling and summer temperature on inflorescence and runner production. Journal of the Japanese Society for Horticultural Science 60(4): 889-895.

Young E. 1989. Cytokinin and soluble carbohydrates concentrations in xylem sap of apple during dormancy and bud break. Journal of the American Society of Horticultural Science 114: 297-300. 